\title{
THE EDITIONS AND TRANSLATIONS OF DR. MATTHEW BAILLIE'S MORBID ANATOMY
}

\author{
by
}

\author{
FRANCO CRAINZ*
}

THE Morbid anatomy by Dr. Matthew Baillie' ${ }^{1}$ is a milestone in the history of the anatomo-pathological literature, being the first systematic treatise on the subject. In the preface to the first edition (pp. vi-viii), Baillie wrote:

Any works explaining morbid structure which I have seen, are very different in their plan from the present: they either consist of cases containing an account of diseases and dissections collected together in periodical publications, without any natural connection among each other; or consist of very large collections of cases, arranged according to some order. In some of these periodical works, the diseased structure has been frequently explained with a sufficient degree of accuracy, but in all the larger works it has been often described too generally. The descriptions too of the principal diseased appearances have been sometimes obscured, by taking notice of smaller collateral circumstances, which had no connection with them or the diseases from whence they arose. Both of these faults even too frequently occur in the stupendous work of Morgagni de Causis et Sedibus Morborum, ${ }^{2}$ upon which, when considered in all its parts, it would be difficult to bestow too high praise ....

In the present work we propose to give no cases; but simply an account of the morbid changes of structure which take place in the thoracic and abdominal viscera, in the organs of generation in both sexes, and in the brain. This will be done according to a local arrangement, very much in the same manner as if we were describing natural structure, and will be accompanied with observations upon morbid actions which may occasionally arise ....

The Morbid anatomy had a large diffusion. In his recent book, ${ }^{3}$ Rodin mentions "eight English editions from 1793 to 1838, three American editions from 1795 to 1820 and several foreign translations - German in 1793, French in 1803, Italian in

\footnotetext{
* Franco Crainz, M.D., F.R.C.O.G., Professor of Obstetrics and Gynaecology, University of Rome.
}

${ }^{1}$ Shotts, Lanark., 27 October 1761 - Duntisbourne Abbots, Glos., 23 September 1823. Lecturer on Anatomy in Dr. William Hunter's School in Great Windmill Street, Haymarket, 1781-1799. B.A., M.A., M.B., M.D., Oxford 1783, 1786, 1786, 1789. Physician to St. George's Hospital, London, 1787-1799. Candidate of the Royal College of Physicians of London 1789, Fellow 1790, Censor 1791 and 1796, Elect 1809. Fellow of the Royal Society of London and of Edinburgh. One of the Trustees of the Medical and Chirurgical Society of London (now Royal Society of Medicine), many times Member of its Council, President 1808 and 1809. Honorary Fellow of the Royal College of Physicians of Edinburgh. Honorary Member of the Medical Societies of Erlangen and of Bonn. Physician-Extraordinary to King George III 1810-1820; Physician-in-Ordinary to Princess Charlotte Augusta 1816-1817. Monument in Westminster Abbey, St. Andrew's Chapel.

2 Giovanni Battista Morgagni, (1682-1771), De sedibus, et causis morborum per anatomen indagatis libri quinque, 2 vols., Venice, Ex Typographia Remondiniana, 1761.

${ }^{3}$ Alvin E. Rodin, The influence of Matthew Baillie's 'Morbid anatomy'. Biography, evaluation and reprint, Springfield, Ill., C.C Thomas, 1973.

4 The correct date 1794 is given at p. 47. 


\section{F. Crainz}

1807, another French edition in 1815, and a Russian one in 1826" (p. 10). In fact, there were two more English editions, four more translations (two into German and two into Italian), an Appendix to the first English edition and its translation into German. Furthermore, the Cox \& Portwine London edition (labelled by the publishers as the eighth) is dated 1833 and not 1838 , as Rodin writes. ${ }^{5}$

In the past years I have looked for Dr. Baillie's works in many libraries in several countries and have collected xerox copies. The following list is, I hope, complete and accurate.

\section{KEY TO THE ABBREVIATIONS}

ALR = Accademia Lancisiana, Rome; BAV = Biblioteca Apostolica Vaticana, Rome; $\mathbf{B E M}=$ Biblioteca Estense, Modena; $\mathbf{B M}=$ British Museum [British Library], London; $\mathbf{B N M}=$ Biblioteca Nazionale Marciana, Venice; $B N N=$ Biblioteca Nazionale, Naples; $B N P=$ Bibliothèque Nationale, Paris; BPF = Biblioteca Provinciale, Foggia; $\mathbf{B P P}=$ Biblioteca Pinali, Padova; $\mathrm{BSB}=$ Bayerische Staatsbibliothek, Munich; BUA = Biblioteca Universitaria Alessandrina, Rome; BUP = Biblioteca Universitaria, Pavia; CPP = College of Physicians, Philadelphia, Pennsylvania; $\mathrm{CRL}=$ Center for Research Libraries, Chicago, Illinois; HLB = Hessische Landesbibliothek, Wiesbaden; IGM = Institut für Geschichte der Medizin der Universität, Vienna; IUB = Indiana University, Bloomington; $\mathrm{JCL}=$ John Crerar Library, Chicago, Illinois; NBV = Nationalbibliothek, Vienna; NLM $=$ National Library of Medicine, Bethesda, Maryland; NSUB $=$ Niedersächsische Staats- und Universitätsbibliothek, Göttingen; NYAM $=$ New York Academy of Medicine, New York; RCP $=$ Royal College of Physicians, London; RCS = Royal College of Surgeons of England, London; SCSML = State Central Scientific Medical Library, Moscow; UBK = Universitätsbibliothek, Kiel; $\quad$ UBM = Universitätsbibliothek, Munich; UBT = Universitätsbibliothek, Tübingen; UBV = Universitätsbibliothek, Vienna; UIMSL = University of Illinois Medical Sciences Library, Chicago; $\mathrm{UKL}=$ University of Kentucky, Lexington; UKMCL $=$ University of Kansas Medical Center Library, Kansas City; ULBSA = Universitäts- und Landesbibliothek Sachsen-Anhalt, Halle; ULCP = Union Library Catalogue of Pennsylvania, Philadelphia; UMAA = University of Michigan, Ann Arbor; UWS = University of Washington, Seattle; WIHM = Wellcome Institute for the History of Medicine, London; YUNH = Yale University, New Haven, Connecticut.

\footnotetext{
'In his book (pp. v, 10, 26, 39, 47) and in his papers 'The influence of Matthew Baillie on disease concepts' (Proceedings of the XXIII International Congress of the History of Medicine, London 1972, 2 vols., London, Wellcome Institute for the History of Medicine, 1974, vol. 1, p. 70) and 'The influence of experience in pathology on two 19th-century practitioners [M. Baillie and W. Osler]' (Texas Rep. Biol. Med. 1974, 32: 137). The wrong date 1838 had already appeared in the Index-Catalogue of the Library of the Surgeon-General's Office, United States Army (2nd Series, 1897, ii, p. 56). In the National /U.S.A.] Union Catalog Pre-1956 Imprints $(1969,31$, p. 3) card 0043759 bears the correct date 1833 and card 0043761 the wrong one.
} 
For the location of more copies of Dr. Baillie's works in Germany and in the U.S.A., see the Deutscher Gesamtkatalog, 1937, 10, columns 16-18, and the National Union Catalog Pre-1956 Imprints, 1969, 31, pp. 2-3.

\section{THE MORBID ANATOMY}

\section{A. ENGLISH EDITIONS}

1. 1793, LONDON. The morbid anatomy of some of the most important parts of the human body. (Printed for J. Johnson, St. Paul's Church-yard; and G. Nicol, Pall-Mall.) Inscribed to Sir George Baker, Bart., President, and the Fellows of the RCP.

8vo; pp. [4], xxviii, 314. BM, CRL, IUB, JCL, NLM, NSUB, NYAM, RCP, RCS, UIMSL, UKMCL, ULCP, UWS, WIHM, YUNH. One of the three copies at the RCP is interleaved, with annotations by Dr. Baillie for the second edition.

2. 1797, LONDON. Idem. The second edition, corrected and considerably enlarged. (Printed for J. Johnson, St. Paul's Churchyard; and G. Nicol, Pall-Mall.) Inscribed to Dr. David Pitcairn.

The additions are principally derived from what I have remarked myself; but they are also taken from the observations of others, and more especially from those of $\mathrm{Dr}$. Soemmerring [v. D1] .... To the Morbid Appearances, I have attempted to subjoin the Symptoms connected with them .... (Preface, pp. [xiii]-xiv).

8vo; pp. [4], xxxvi, 460. BNP, CPP, NLM, NYAM, RCP, RCS, ULCP, WIHM.

3. 1798, LONDON. An appendix to the first edition of the morbid anatomy of some of the most important parts of the human body. (Printed for J. Johnson, St. Paul's Churchyard; and G. Nicol, Pall-Mall.)

The Author thought it an act of justice, due to those who had purchased copies of the first Edition of the Morbid Anatomy, to publish an Appendix to it. This not only comprehends what is new in the second Edition, but also whatever has undergone any considerable alteration since the publication of the first .... (Advertisement, p. [iii]).

8vo; pp. xvi, 162. CRL, NSUB, RCS. Not in Rodin.

4. 1807, LONDON. The morbid anatomy of some of the most important parts of the human body. The third edition, corrected. (Printed by $\mathrm{W}$. Bulmer and Co. Cleveland-Row; for J. Johnson, St. Paul's Churchyard; and G. and W. Nicol, Pall-Mall.) Inscribed to Dr. David Pitcairn.

For the last seven years I have been so much engaged in the practical duties of my profession, as only to have had occasional opportunities of inspecting dead bodies. I have, therefore, scarcely been able to make any additions to this work, but I have made such corrections of it, as more reflection and experience have suggested to me .... (Advertisement, p. [xxi]).

8vo; pp. [4], xl, 461. BM, NLM, RCP, WIHM, YUNH. 


\section{F. Crainz}

5. 1812, LONDON. Idem. The fourth edition, corrected. (Printed by W. Bulmer and Co. Cleveland-Row; for G. and W. Nicol, Pall-Mall; and J. Johnson and Co. St. Paul's Churchyard.) Inscribed to Dr. David Pitcairn. 8vo; pp. [4], xl, 470. BM, RCP, RCS, ULCP, WIHM.

6. 1818, LONDON. Idem. The fifth edition, corrected. (Printed by W. Bulmer and Co. Cleveland-Row; for G. and W. Nicol, Pall-Mall; and E. Cox and Son, St. Thomas's Street, Southwark.) Inscribed to Dr. David Pitcairn.

The present edition of my book is somewhat enlarged, and is corrected, according as some of my observations have appeared to be extended or limited by greater experience. (Advertisement, p. [xxiii]).

8vo; pp. [4], xliii, 482. Pp. 31-32, the last two pages of gathering $C$, were printed again as the first two pages of gathering $D$. (In many copies the first couple was torn away.) Therefore the signatures D, E, F, . . Ii are on pp. 31, $47,63, \ldots 479$, instead of on pp. 33, 49, 65, . . 481. BM, CPP, NLM, NYAM, RCP, RCS, UBT, ULCP, WIHM.

7. 1825, LONDON. Idem. To which are prefixed, preliminary observations on diseased structures, by the Editor. In: The works of Matthew Baillie, M.D., by James Wardrop ... ii [i:v. Appendix 1]. (Printed for Longman, Hurst, Rees, Orme, Brown, and Green, Paternoster-Row.)

8vo; pp. Ixxii, 407. JCL, NLM, NSUB, RCP, RCS, UKL, UKMCL, ULBSA, ULCP, WIHM, YUNH.

8. 1830, LONDON. Idem. The sixth edition. With preliminary observations on diseased structures, and notes: by James Wardrop .... (Printed for Longman, Rees, Orme, Brown, and Green.) Copies of No. 7, in which pp. [i]-vi have been reprinted. WIHM. Not in Rodin.

9. 1830, LONDON. Idem. A new edition. (Printed for Edward Limebeer, 19, Giltspur Street, four doors from St. Bartholomew's Hospital.)

8vo; pp. xv, 248. NLM, RCP, RCS, UBT.

10. 1833, LONDON. Idem. The eighth edition. (John Thomas Cox, 84, High Holborn. And Edward Portwine, Carthusian Street.)

16mo; pp. xvi, 281. NLM, WIHM. Rodin: 1838.

11. 1833, LONDON. Idem. To which are prefixed, preliminary observations on diseased structures. By James Wardrop .... (Printed for Longman, Rees, Orme, Brown, Green, \& Longman, Paternoster-Row.)

16mo; pp. xvi, 343. BM, NLM, RCP, ULCP. Not in Rodin.

B - AMERICAN EDITIONS

1. 1795, AlBANy. Idem. The first American edition. (Printed by Barber \& Southwick, for Thomas Spencer, Bookseller, Market Street.)

8vo; pp. [4], viii, 248, [12]. CPP, IUB, NLM, NYAM, RCS, UKMCL, ULCP, YUNH. 
2. 1808, WAlpole, N. H. Idem. The second American, from the third London edition .... (Printed by G. W. Nichols, for W. Fessenden, Bookseller, Brattleborough, Vt.)

8vo; pp. xi, [13] - 271. CPP, CRL, JCL, NLM, UKL, ULCP, WIHM, YUNH.

3. 1820, Philadelphia. Idem. Third American from the fifth London edition. (Printed and published by Hickman and Hazzard, No. 15, North Front Street.)

8vo; pp. xx, 288. BM, CPP, JCL, NLM, RCP, UKL, UKMCL, ULCP, UMAA, YUNH.

\section{C - TRANSLATIONS INTO FRENCH}

1. 1803, PARIS. Traité d'anatomie pathologique du corps humain. Traduit de l'anglois, sur la dernière édition ... Par M. Ferrall ... (Chez Samson, Libraire, quai des Augustins, $n^{\circ}$. 69, près le Pont-Neuf.) 8vo; pp. xvi, 454. BSB, BUA, BUP, NLM, RCP, RCS, WIHM.

2. 1815, PARIS. Anatomie pathologique des organes les plus importans $d u$ corps humain. Ouvrage traduit de l'Anglais, et enrichi de notes ... par M. Guerbois ... (Chez l'Auteur, au Collège, rue Saint-Jacques, N. 123; Chez Crochard, Libraire, rue de l'École de Médecine, $N^{\circ}$. 3.) 8vo; pp. xxxii, 404. BNP, BPP, NLM, RCP, RCS, WIHM.

\section{D - TRANSLATIONS INTO GERMAN}

1. 1794, BERLIN. Anatomie des krankhaften Baues von einigen der wichtigsten Theile im menschlichen Körper. Aus dem Englischen mit Zusätzen von S. Th. Sömmering. (In der Vossischen Buchhandlung.)

8vo; pp. xxviii, 268. BSB, CPP, JCL, NLM, NSUB, RCP, RCS, UBK, UBM, UBT, UBV, ULBSA, ULCP, UMAA, WIHM.

2. 1803, LEIPZIG. Neue Bemerkungen über die Anatomie des krankhaften Baues von einigen der wichtigsten Theile des menschlichen Körpers. In: Sammlung auserlesener Abhandlungen usw., 20, parts 3-4. (Im Verlage der Dyckischen Buchhandlung.) Translation of A3 (by E. B. G. Hebenstreit?). 8vo; pp. [323] - 478; contents: pp. 643-644. Not in Rodin. IGM, RCS.

3. 1805, VIENNA. Anatomie des krankhaften Baues von einigen der wichtigsten Theile im menschlichen Körper. Aus dem Englischen mit Zusätzen von Sam. Thom. Sömmering. Zweyte Auflage ..... In: Auserlesene medizinische Bibliothek usw., part 45. (Mit v. Ghelenschen Schriften.)

8vo; = Dl + D2. Dl: pp. xvi, 268; contents: p. 383. D2: Matthew Baillie's Zusätze zu seiner Anatomie von einigen der wichtigsten Theile des menschlichen Körpers. Pp. [269]-382; contents: p. 384. In some copies p. [i], with the indication Auserlesene medizinische Bibliothek usw., was torn away. Not in Rodin. HLB, IGM, UBM, UBV, ULCP. 


\section{F. Crainz}

4. 1820, BERLIN. Ibid. Aus dem Englischen. Mit einem nach der fünften Original = Ausgabe und mit neuen Anmerkungen des Geheimen Rath von Sömmerings vermehrte Anhange. Neue Auflage (In der Vossischen Buchhandlung.)

Copies of D1 with a new title-page and with an Appendix: Anhang zu Mathew Baillie's . . Anatomie ... übersetzt von Dr. Carl Hohnbaum ... Anhang: pp. xvi, 184. Not in Rodin. BAV, RCP (only the Anhang), RCS, UBT, ULBSA.

\section{E - TRANSLATIONS INTO ITALIAN}

1. 1807,6 PAVIA. Trattato di anatomia patologica del corpo umano. Tradotto, ed accresciuto di note sull'ultima edizione dal Dottore Pietro Gentilini. (Nella Tipografia di Giovanni Capelli.)

8vo; pp. xiii, 280. BEM, BNN, BPP, BUP, NLM, RCP, WIHM.

2. 1808, NAPLES. Trattato di notomia patologica del corpo umano. Prima edizione napolitana con note del Dottor G.G. (Presso Vincenzo Orsino.)

$8 v o$; i: pp. xv, 163; ii, pp. 221. (Many pages of ii are wrongly numbered.) Not in Rodin. BNN, BPF.

3. 1819, vENICE. Anatomia patologica di alcune fra le parti più importanti del corpo umano. Tradotta dalla quarta edizione inglese dell'anno 1812. Da Paolo Zannini .... Con la giunta delle Appendici e di un sunto delle Annotazioni del Sig. Sam. Tom. Soemmering, e di altre annotazioni del Traduttore Italiano. (Per Giuseppe Picotti. In other copies: A spese del negozio di libri all'A pollo co'tipi picottiani.)

8vo; i: pp. xl, 403 (Text: [1]-249; Sömmering's and Translator's notes: [251]-403); ii: pp. [10], 416 (Text: [1]-299; Sömmering's and Translator's notes: [301]-387; Index: [389]-416. Not in Rodin. ALR, BAV, BEM, BNM, BNN, BPP, BUP, RCP, RCS, UBV.

\section{F - TRANSLATION INTO RUSSIAN}

1. 1826, MOSCOW. Patologičeskaja Anatomija važnejših" častej tela čelovečskago, preimušcestvenno nahodjašcihsja v" glavnyh" četyreh" polostjah". Perevel" s" Anglijskago pjatago ispravlennago izdanja, s" pojasnutel'nymi i dopolnitel'nymi primečanijami i prisovokupil" svoj Traktat" ob" otnošenijah" Patologičeskoj Anatomii k" drugum" Vračevnim" Naukam", i o sposobah", koimi ona možet vyt' poznavaema i soveršenstvuema, s" predvaritel'nim" korotkim izloženiem" eja Istorii, Ivan" Kostomarov". (BI Tipografii P. Kuznesova.) [The morbid anatomy of the most important parts of the human body chiefly situated in the four main cavities. Translated from the 5th corrected edition with explanatory and complementary comments. To this

'In Rodin: op. cit., note 3 above: 1807 at pp. 10 and 26, 1815 at p. 47. 
has subjoined Ivan Kostomarov his own Treatise on the relation of morbid anatomy to other medical sciences, as well as on methods with the help of which it may be cognizable and perfected, with an addition of a short preliminary account of its history.]' (In the printing-house of P. Kuznesov.) 8vo; pp. [8], xxvii, ii, 233. SCSML.

\section{THE ENGRAVINGS FOR THE MORBID ANATOMY}

1. 1799-[1802], LONDON. A series of engravings, accompanied with explanations, which are intended to illustrate the morbid anatomy of some of the most important parts of the human body. Fasciculus I .... (Printed by W. Bulmer and Co. and sold by J. Johnson, St. Paul's Churchyard; and G. Nicol, PallMall.)

It seemed to me,... to be an important desideratum in Anatomy, to comprehend in one
work, upon some regular plan, Engravings of the chief Morbid Changes of Structure .... I
have, therefore, ventured to undertake such a Work; but only propose to proceed in it a little
way, till the opinion of the Public with regard to it is collected ... The order of the Engrav-
ings will correspond very much with that of ... my book upon Morbid Anatomy; but the two
works will be made independent of each other. The Engravings will be accompanied with
such a Description as to be perfectly understood, without any reference to the volume upon
Morbid Anatomy.... (Advertisement, pp. [3]-5). Nine more Fasciculi (II-X) were published between 1799 and 1802. They have no title-page, but the plates are dated (Fasc. II: 24 June 1799; III: 25 (or 27) January 1800; IV: 20 June 1800; V: 1 November 1800; VI: 1 March 1801; VII: 20 July 1801; VIII: 1 December 1801; IX: 20 April 1802; X: 30 October 1802.) The plates of Fasc. I (1799) are dated 8 December 1798.

Large 4to; pp. 228; 73 plates, with 206 figures. The first gathering [A] contains the title-page (p. [1]) and the Advertisement (pp. [3]-7). Each Fasciculus begins with a new signature ([A],D,G,L,P,S,X,Aa,Dd,Gg) even if the number of the pages of the preceding one is not a multiple of 8 (Fasc. II has 20 pages; III: 22; IV: 30; V: 22; VI: 20; VII: 20). Last signature: Ii (p. 223). BSB, CRL, JCL, NLM, NSUB, RCP, RCS, UBK, UKL, WIHM.

2. 1803, LONDON. A series of engravings, ... of the human body; divided into ten Fasciculi. (Printed by W. Bulmer and Co. for J. Johnson, St. Paul's Churchyard; and G. and W. Nicol, Pall-Mall.)

Only Fasc. I was printed again in slightly larger types (therefore some lines have less words and some paragraphs more lines). The first gathering ([A]) contains the half-title (p. $\left.\left[\pi_{2}{ }^{r}\right]\right)$, the title-page (p. $\left.\left[\pi_{2}{ }^{r}\right]\right)$, an inscription to Dr. David Pitcairn, dated 30 October 1802 (pp. [i]-ii) and the Advertisement (pp. [3]-7). Fasc. $X$ is followed by seven unnumbered pages (Sig. Kk) of

\footnotetext{
${ }^{7} \mathrm{~J}$. A. Shilinis, 'On the history of the Russian-British connexions in general pathology', Proceedings ...., op. cit., note 5 above, vol. 1, p. 848 .
} 


\section{F. Crainz}

Index. BM, NLM, RCS, ULCP, YUNH. (N.B.: the inscription to Dr. Pitcairn was inserted in some copies with the 1799 title-page, or the 1803 titlepage and the inscription were put in front of copies of Fasc. I printed in 1799.)

3. 1812, LONDON. Idem. The second edition. (Printed by W. Bulmer and Co. Cleveland Row; and sold by G. and W. Nicol, Booksellers to His Majesty, Pall-Mall.)

Like No. 2. The volume having been printed as a whole, all the gatherings have 8 pages (Sig.: [A]-Z, 2A-2F). No Index. BM, CPP, CRL, JCL, NLM, RCP, RCS, UBM, UBT, UKMCL, ULCP, UWS, WIHM, YUNH.

\section{APPENDIX}

Besides the Morbid anatomy and the explanations to the Engravings, Dr. Baillie wrote a number of short papers. Twenty were published in Philosophical Transactions, of the Royal Society of London (1788, 78, ii, 350-3638; 1789, 79, i, 71-789), in Transactions of a Society for the improvement of medical and chirurgical knowledge (1793, 1, 91-102, 119-137, 189-201, 202-211; 1800, 2, 70-89,10 144-151, 174-183; 1812, 3, 7-23, 258-262, 263-267, 275-289'1), and in Medical Transactions, published by the College of Physicians in London (1813, 4, 1-8, 9-15, 271-277; 1815, 5, $136-142,143-148,166-172 ; 1820,6,16-26)$.

These twenty ${ }^{12}$ papers and two more, together with the reports of thirty-nine dissections, were collected in a volume two years after Dr. Baillie's death.

1. 1825, LONDON. The works of Matthew Baillie, M.D. To which is prefixed, an account of his life, collected from authentic sources. By James Wardrop ... In two volumes. i [ii: $v$ A7]. (Printed for Longman, Hurst, Rees, Orme, Brown, and Green, Paternoster-Row.)

8vo; pp. Ixxiii, 237. JCL, NLM, NSUB, RCP, RCS, UIMSL, UKL, UKMCL, ULBSA, ULCP, UWS, WIHM, YUNH.

A German translation was published twice.

1a. 1829, HALBERSTADT. Matth. Baillie, D.M. Beiträge zur praktischen Arzneiwissenschaft und pathologischen Anatomie. Aus dem Englischen vom Dr. I. G. Leukfeld (bei Carl Brüggemann.)

8vo; pp. [2], vi, [7]-182. (Title page [ $\left.\pi_{1} \tau\right]$; Leukfeld's preface [i]-ii; Contents [iii]-[iv]; Half title [v]). In some copies the table of contents is at the end of the book. IGM, NBV, UBK, UBV.

- An abridged version was published in Phil. Trans. R. Soc. Lond., 1809, 16 (from 1785 to 1790): 483-489, and reprinted in F. A. Willius and T. E. Keys, Cardiac classics, London, H. Kimpton, 1941, pp. $257-262$.

'Reprinted in Lond. med. J., 1789, 10, iii: 322-332. An abridged version was published in Phil. Trans. $R$. Soc. Lond., 1809, 16 (from 1785 to 1790): 535-539.

${ }^{10} \mathrm{~A}$ translation into German appeared in Sammlung auserlesener Abhandlungen usw., 1803, 20, parts $3-4,582-597$.

"One of the "three cases of inflammation of the inner membrane of the larynx and trachea terminating quickly in death" was Dr. David Pitcairn (d. 17 April 1809).

12 One was divided into three parts and therefore they seem to be twenty-two. 
1b. 1838, LEIPZIG. Dr. I. G. Leukfeld's Darstellung höchst wichtiger Krankheitsfälle. Für Aerzte und Anatomen. Nach dem Englischen des Dr. Matth. Baillie (bei Ludwig Schreck.)

Like la, with a different title-page and half-title and without Leukfeld's preface (Title-page [i]; Contents [iii]-[iv]; Half-title [v]). IGM.

Another volume of collected works appeared also posthumously.

2. 1825, LONDON. Lectures and observations on medicine. By the late Matthew Baillie, M.D. (Printed by Richard Taylor.) In his will Dr. Baillie wrote:

I wish my two Introductory Lectures to the course of Anatomy which I gave in Great Windmill Street, my Lectures upon the Nervous System read before the College of Physicians, and a short account of my experience in the Practice of Medicine, to be printed, but not published. One hundred and fifty copies may be printed, of which one copy may be given to each of my more intimate medical friends, and the remainder to the Royal College of Physicians in London. (Introduction, p. [v]-vi.)

8vo; pp. ix, 242. BM, NLM, RCP, RCS, UKMCL, ULCP, WIHM.

A German translation was published twice.

2a. 1827, LEIPZIG. Medicinische Vorlesungen und Beobachtungen von Mathäus Baillie, M.D. Als Manuscript für Freunde gedruckt und aus dem Englischen übersetzt von Dr. Carl Hohnbaum ... (bei C. H. F. Hartmann.) In: Bibliothek der ausländischen Literatur für praktische Medicin, 6. 8vo, pp. viii, 179. NBV, NSUB, UBK, UBM, UBT, UBV, ULBSA.

2b. 1839, LEIPZIG. Dr. Mathäus Baillie's medicinische Vorlesungen und Beobachtungen. Als Manuscript ... (Verlag der Lenhold'schen Buchhandlung.) In: Bibliothek der ausländischen Literatur ... Wohlfeile Gesammtausgabe, 5.

Like 2a, with a new title page (p. [iii]), which bears also the indication Bibliothek, usw., at p. [ii] in 2a. ULBSA.

Dr. Baillie's bibliography includes two more items:

3. The edition of An anatomical description of the human gravid uterus, and its contents, by his maternal uncle Dr. William Hunter (J. Johnson and G. Nicol, London 1794.) $)^{13}$

4. A letter about "scirrhous structures" written in 1796 to Dr. Joseph Adams and included in Adams' book Observations on the cancerous breast ... (T. N. Longman and $\mathrm{O}$. Rees, London 1801, pp. 32-36). Two passages from another letter are quoted at p. 29 (about the term "hydatid") and in a footnote at p. 27 (about carcinoma).

${ }^{13}$ A translation into German by L. F. Froriep was published in 1802 in Weimar (im Verlage des Landes = Industrie = Comptoirs: D. William Hunter's anatomische Beschreibung des schwangeren menschlichen Uterus. 


\section{F. Crainz}

The subject of Dr. Baillie's letters published by G. C. Peachey ${ }^{14}$ and by J. Roberton ${ }^{15}$ is not medical.

There is no evidence that A. Chrichton's book An account of some experiments made with the vapour of boiling tar, in the cure of pulmonary consumption (Manners and Miller, Edinburgh, and T. and G. Underwood, London, 1817) was edited by Dr. Baillie, as it is stated in the BM General Catalogue and in the Deutscher Gesamtkatalog.

In the National [U.S.A.] Union Catalog pre-1956 Imprints Matthew Bailey (not Baillie!) is a character in B. W. Richardson's book The guild of good life, first published in 1884 (card 0043745). A Paris 1803 edition in German of The morbid anatomy (card 0043740) does not exist. The Matthew Baillie in the unnumbered card between 0043733 and 0043735 was a Scottish surgeon who took his medical degree in Edinburgh in 1823, a few weeks before the death of the morbid anatomist, of whom he was not a near relative.

14 G. C. Peachey, 'Two unpublished letters of Matthew Baillie, M.D. With annotations', Ann. med. Hist., 1931, N.S. iii: $404-406$.

is J. Roberton, Letters from Dr. Baillie, with remarks, London, J. J. Stockdale, 1817, 43 pp. This pamphlet was inserted between p. [viii] and p. [ix] in the fourth edition (1817) of Roberton's book On the generative system etc.; it is mentioned in the title-page but not in the table of contents. 